\title{
Deslizar nas ruas, entre Max Jacob e Mário de Andrade
}

\author{
Pablo Simpson ${ }^{1}$
}

\section{Resumo}

Este ensaio pretende apontar para um possível diálogo entre Mário de Andrade e Max Jacob, a partir dos livros de poemas Paulicéia desvairada (1922) e O losango cáqui (1926), Le cornet à dés (1916) e Le laboratoire central (1921). Organizado em três partes, investiga a figuração nos dois poetas da imagem do arlequim, por meio da qual ambos operariam diversos deslocamentos. Um deles, a retomada de uma mitologia romântica do artista, como em Baudelaire, e a consciência de seu caráter de encenação. Outro, através da oposição entre razão e loucura, legitimando um estado lírico como modo distinto de percepção da realidade. Finalmente, por intermédio da proposição de uma sinceridade artística, moral do trabalho com profunda repercussão sobre a linguagem literária.

\section{Palavras-chave}

Mário de Andrade, Max Jacob, arlequim, poesia moderna, vanguardas.

Recebido em 17 de junho de 2010

Aprovado em 6 de junho de 2011

1 Pablo Simpson é Doutor em Teoria e História Literária pela Unicamp e Pós-Doutor em Literatura Geral e Comparada pela Université Sorbonne Nouvelle/Fondation Maison des Sciences de l'Homme-Paris e pela Universidade de São Paulo/Fapesp, com projeto sobre a poesia cristã francesa no século XX e sua recepção no modernismo brasileiro, de que este ensaio é um dos desdobramentos. Atualmente é professor de Literatura e Civilização Brasileira na Université de Yaoundé I no Cameroun.E-mail: simpson.pablo@gmail.com 


\section{Slide on the streets, between Max Jacob and Mário de Andrade}

\section{Pablo Simpson}

\section{Abstract}

This essay intends to point to a possible dialogue between Mário de Andrade and Max Jacob, starting from the books of poems Paulicéia desvairada (1922) and O losango cáqui (1926), Le cornet à dés (1916) and Le laboratoire central (1921). Divided into three parts, it investigates the figuration in the two poets of the harlequin's image, through which both would operate several displacements. One of them, the resumption of a romantic mythology of the artist, as in Baudelaire, and the conscience of his staging character. Other, through the opposition between reason and madness, legitimating a lyrical state as a way to a different perception of the reality. Lastly, through the proposition of an artistic sincerity, moral of work with deep impact over the literary language.

\section{Keywords}

Mário de Andrade, Max Jacob, harlequin, modern poetry, avantgardes. 


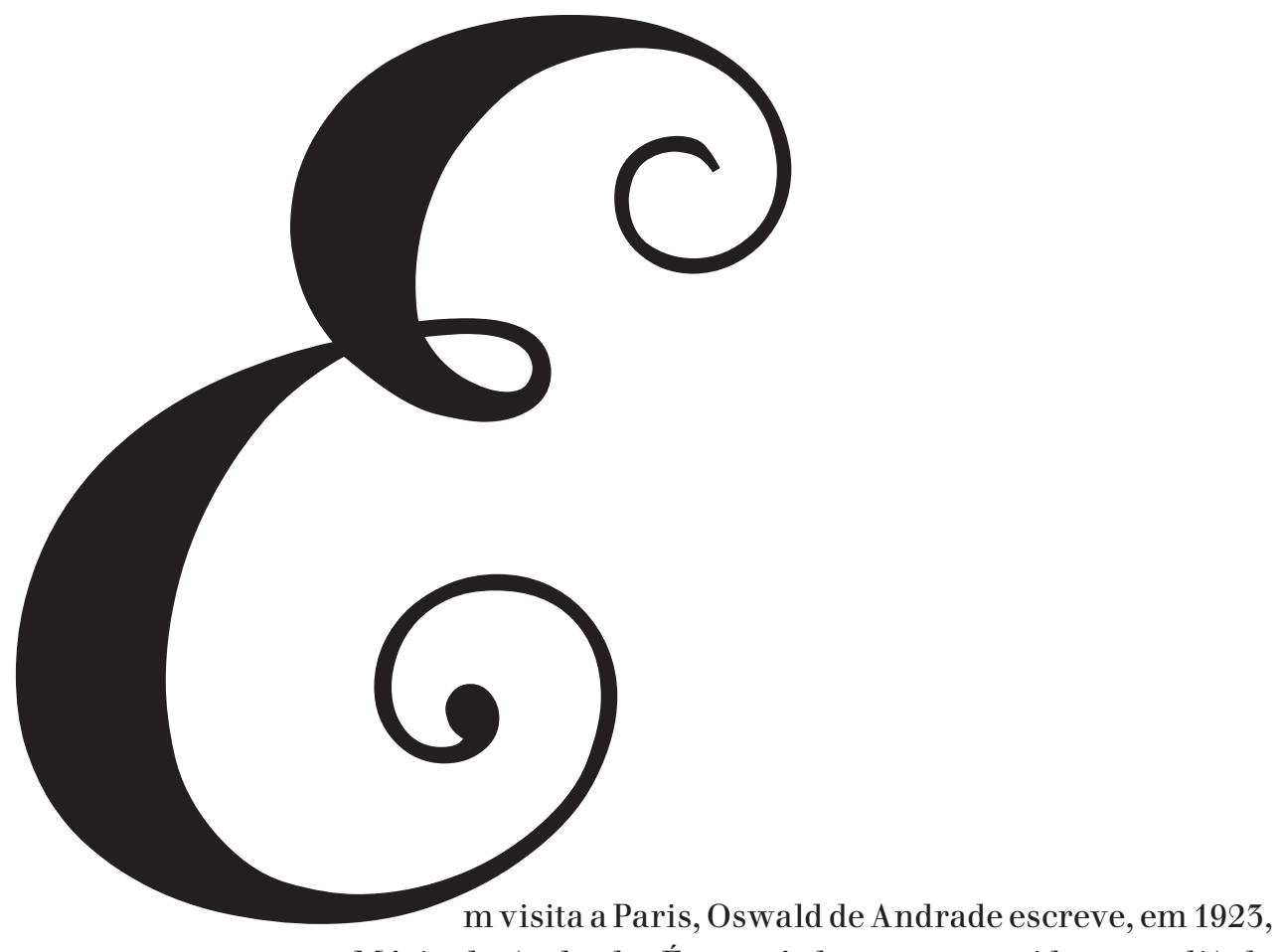
uma carta a Mário de Andrade. É o período em que reside no ateliê de Tarsila, um mês antes de pronunciar a conferência "O esforço intelectual do Brasil contemporâneo" na Universidade da Sorbonne. A carta evoca a familiaridade com Pablo Picasso e Jean Cocteau, tão receptivos. Há nela uma breve menção a Max Jacob; Oswald não consegue visitá-lo: "esse um dos únicos 'moderníssimos' a ser levado a sério, ao lado de Blaise Cendrars e Cocteau" ${ }^{2}$. Numa época de grande efervescência artística, o poeta francês de origem judia se mudara para o convento de Saint-Benoîtsur-Loire. Convertido ao catolicismo, cumpre o que havia previsto, não sem ironia, ao rei de um poema de Le laboratoire central (1921).

Et le vieu roi prit le chemin du monastère, Cette retraite stupéfia l'univers.

[E o velho rei se encaminhou ao monastério, Essa retirada espantou o mundo inteiro. $]^{3}$

2 ANDRADE, Oswald de. Telefonema, Obras completas, 10. Rio de Janeiro: MEC/Civilização brasileira, 1974. p. 41-42.

3 JACOB, Max. Le laboratoire central. Paris: Gallimard, 1960. p. 86. Salvo menção, todas as traduções são minhas.

IO9 revista ieb n53 2011 mar./set. p. I07-I26 
Mário de Andrade escreveu sobre Max Jacob em poucas oportunidades. Há uma menção em A escrava que não é Isaura ${ }^{4}$, outra em sua correspondência com Henriqueta Lisboa ${ }^{5}$, outras mais: num artigo publicado no Jornal do Comércio de São Paulo ${ }^{6}$, num ensaio sobre Luís Aranha ${ }^{7}$ e numa carta a Pedro Nava, ao indicar-lhe uma correspondência recémenviada a Drummond. Nela anexou o artigo polêmico de Oswald de Andrade, publicado em 1927, sobre Amar, verbo intransitivo, em que este o chamara de "Max Jacob do Bairro do Limão"8. Incomodado com a comparação, embora tenha afirmado a Nava que continuariam amigos, dessa época advém a ruptura definitiva entre os dois poetas. Conforme sugestão de Manuel Bandeira, meses antes: “do Oswald só há dois meios de se defender: ou fazer mais blague e mais intriga do que ele ou então afastar-se" .

Max Jacob não é, portanto, o poeta francês das predileções públicas de Mário de Andrade. Não ocupa o mesmo espaço destinado a Arthur Rimbaud, sobre o qual teorizara em A escrava que não é Isaura"vagabundo genial" que teria descoberto a poesia moderna - ou a Louis Aragon, que afirmara ser em 1932 "o poeta mais verdadeiramente poeta da França atual"10. Não produziu, ademais, o deslumbramento das Villes tentaculaires (1895), do belga Émile Verhaeren, no momento da elaboração de Paulicéia desvairada.

4. ANDRADE, Mário de. Obra imatura. São Paulo/ Belo Horizonte: Martins/Itatiaia, 1980. p. 245 .

5 "Estou mais ou menos convencido que o que deviam fazer era pegar em mim, botar num desses sanatórios de loucos mansos, ‘superiores' como diz Max Jacob, e não deixar eu ler, nem fumar, nem escrever, nem pensar por um mês”. Carta de 12 de setembro de 1943. In: ANDRADRE, Mário de. Querida Henriqueta: cartas de Mário de Andrade a Henriqueta Lisboa. José Olympio: Rio de Janeiro, 1991. p. 131.

6 A referência é de Sérgio Buarque de Holanda e pode ser encontrada no capítulo: Guilherme de Almeida. In: PRADO, Antonio Arnoni (Org.). O espírito e a letra: estudos de crítica literária, v. 1, São Paulo: Companhia das Letras, 1996. p. 11 .

7 Cf. Luís Aranha ou a poesia prepatoriana. Revista Nova, São Paulo, julho de 1932.

8 Carta de Mário de Andrade a Pedro Nava de 10 de abril de 1927: "Mandei pro Drummond um artigo em que o Oswald fala do Amar, verbo intransitivo falando que não gostou. É verdade que espirrou besteira pra burro, me chamou de fazendo Max Jacob, pedi que provasse e embatucou, etc. Porém isso não tem a mínima importância, continuamos amicíssimos". Drummond, alguns anos antes, colocara o poeta francês ao lado de autores como Proust, Cendrars, Joyce e Conrad, ao opor-se a uma ideia de poesia nacional primitiva (a referência é a Oswald). Carta de zo de dezembro de 1924 a Mário de Andrade. In: SANTIAGO, Silviano (Org.). Carlos e Mário. Rio de Janeiro: Bem-te-vi, 2ooz. p. 297 (em nota) e 79-8o, respectivamente.

9 MORAES, Marcos Antônio de (Org.). Correspondência Mário de Andrade \& Manuel Bandeira. São Paulo: Edusp/IEB, 2001. p. $3^{26 .}$

10 ANDRADE, Mário de. Intelectual - II. In: Táxi e crônicas do Diário Nacional. Estabelecimento de texto, introdução e notas de Telê Porto Ancona Lopes. São Paulo: Duas Cidades, 1976. p. 520. 
Max Jacob não foi lido, do mesmo modo, como Jean Cocteau ou Apollinaire em sua conferência sobre "L'esprit nouveau et les poètes", traduzida por Gilberto Mendonça Teles, que apontou para o seu impacto sobre o poeta paulista, como o fizera Maria Helena Grembecki ${ }^{11}$. Nele não se encontra a noção de sujeito lírico polifônico, presente em Blaise Cendrars, cujo modelo seria a orquestra de jazz, tão cara a algumas das teorizações do autor de Macunaíma, que vai incorporá-la a uma reflexão poético-musical.

Importante, apesar disso, para as primeiras vanguardas - por uma nova inflexão conferida à expressão poética, mais livre, mais cotidiana, ou pela suposta criação, como gostava de afirmar, do gênero do poema em prosa - , Max Jacob foi em parte também esquecido pela crítica francesa, incapaz de situá-lo face às vertentes de seu tempo. Para Christine Van Rogger-Andreucci, suas escolhas estéticas o mantiveram sob a desconfiança dos meios religiosos ou da renovação católica, como caracterizara Jean Calvet em seu Renouveau catholique dans la littérature contemporaine, de 1931. Por outro lado, a adoção da prática religiosa o afastou do convívio com as estéticas mais revolucionárias. O surrealismo evita reconhecê-lo como precursor. Num catálogo de publicações, também de 1931, uma advertência surpreende: "Não leiam: Claudel, Péguy, Proust, Valéry, Mauriac e Max Jacob"12.

É possível que Mário de Andrade tenha tomado contato com algumas dessas recusas. Cendrars, por exemplo, diria em 1927 não pensar "tão bem dos escritores modernos que se converteram ao Catolicismo como Max Jacob, Reverdy e Cocteau [...], são sobretudo homens fatigados"13. Além disso, as teorizações sobre o inconsciente, a ironia, a liberdade ou o choque de imagens - em Max Jacob, "mots en liberté, associations hasardeuses des idées, rêves de la nuit et du jour"14 - fundem-se no autor de Macunaíma a uma reflexão sobre a nacionalidade que o poeta francês não perseguiria, ou a um projeto de arte popular, por vezes primitiva, legitimado pelas vanguardas europeias, no caso da obra pictórica de Henri Rousseau ou das artes africanas, mas pouco abrangente para a poesia, ainda que Paul Claudel pudesse vislumbrá-lo na poética selvagem e religiosa de Rimbaud.

A reflexão de Mário de Andrade se constituiria, ademais, na proximidade com uma teoria musical ou rítmica, relativamente apartada de uma

11 TELES, Gilberto Mendonça. Vanguarda européia e modernismo brasileiro. 3. ed. Rio de Janeiro: Vozes/ INL, 1976.

12 VAN ROGgER-ANDREUCCI, Christine. Poésie et religion dans l'œuvre de Max Jacob. Paris: Honoré Champion, 1994. p. 19.

13 EULÁLIO, Alexandre. A aventura brasileira de Blaise Cendrars. 2. ed. rev. ampl. por Carlos Augusto Calil. São Paulo: Edusp/ Fapesp/ Imprensa Oficial, 2ool. p. 420.

14. Petit historique du Cornet à dés (1947). In: JACOB, Max. Le cornet à dés. Paris: Gallimard, 2003. 
preocupação teórica com a noção de imagem, frequente em Jacob, que esteve próximo a Pierre Reverdy, e cujas telas viriam ao Brasil para a exposição L'École de Paris, em 1930 - que Mário comentou. Não se pode dizer, por fim, que o catolicismo de Max Jacob repercuta o mesmo sentimento religioso de Mário de Andrade, embora este tenha afirmado que "todos nós estamos presos por ligações irremovíveis a Jesus"15. Na crônica "Decoratismo I", publicada no Diário Nacional em 1929, diferentemente, observaria “a contradição primordial entre o artista verdadeiro e os deveres morais que uma religião como a Católica, por exemplo, impõe aos homens"16.

\section{O rei de Tule e a loucura}

Na primeira poesia de Mário de Andrade de Paulicéia desvairada (1922) e O losango cáqui (1926), contudo, há momentos em que se fazem ouvir ecos da poética de Max Jacob, autor tão presente na biblioteca do poeta brasileiro ${ }^{17}$. Ecos dispersos, misturados a tantos outros, numa opção por um ecletismo adolescente, nas palavras de Telê Ancona Lopez, capaz de agregar fontes variadas, como o dadaísmo, o expressionismo, o unanimismo, o futurismo e o cubismo, a um projeto de compreensão de nossa realidade ${ }^{18}$. Dois poetas arlequins, essa uma das imagens centrais da primeira poética de Mário e de Max Jacob, desdobrando-se em múltiplos registros: da ironia à seriedade, das odes corais aos poemas curtos. E múltiplos assuntos: da política nacional ao debate artístico, passando por menções a leituras, de Dostoievski à poesia oriental em Le cornet à dès, de Freud a Bilac no "Prefácio interessantíssimo".

O arlequim está no esboço para a capa da Paulicéia desvairada, posteriormente reduzido aos famosos losangos coloridos ${ }^{19}$. Está também no livro Dos d'arlequin de Max Jacob, publicado em 1921, que reunia, a um breve texto dramático, ilustrações do poeta gravadas em madeira ${ }^{20}$. Figuram-no como a própria personagem, como o fizeram artistas como Pablo

15 ANDRADE, Mário de. Taxi e crônicas do Diário Nacional. op. cit, p. 447.

16 Idem, ibidem, p. 139 .

17 Com livros como La défense de Tartufe (1919), Cinématoma (1920), Dos d'arlequin (1921), Le laboratoire central (1921), Le roi de Béotie (1921), Art poétique (1922) e Le cornet à dés (1923).

18 LOPEZ, Telê Ancona. Arlequim e modernidade. In: - Mariodeandradiando. São Paulo: Hucitec. p. 17 e 32. Telê, num ensaio que é fonte desta pesquisa, percorreu várias dessas figurações do arlequim, além do contato de Mário com o Arlecchino de Soffici.

19 Idem, ibidem, p. 20.

20 Uma delas é reproduzida no caderno de imagens desta revista, a partir da edição que consta da Coleção Mário de Andrade do Instituto de Estudos Brasileiros da USP. 
Picasso na primeira edição de Le cornet à dés, muito embora este tenha preferido, diz-se, representá-lo como um monge em Les trois musicians (1921), vestindo a si mesmo como arlequim e a Apollinaire como pierrô.

Da capa e das ilustrações o arlequim salta para o interior dos poemas. Em Max Jacob, num poema como "Poème dans un goût qui n'est pas le mien", evidencia-se a filiação a Baudelaire, a quem o poema é dedicado. Filiação marcada pela distância do "gosto que não é o meu", como se o poeta pudesse escrever assumindo outras vozes, encenando um objeto artístico "afastado do sujeito" e de uma certa "realidade" - esse o ideal de arte do prefácio de 1916 de Le cornet à dés, no qual teorizou sobre o poema em prosa. Tal encenação permite-nos caracterizar o arlequim sob a figura do alter ego, que surge num primeiro momento através do tema do estilo, considerado por Max Jacob como "a elaboração dos materiais e a composição do conjunto, não como a língua do escritor", estilo "que separa", que dá "a sensação de fechado" "21. E que faz com que a obra de arte seja "situada" - esse o outro termo da teoria de Jacob. Situada, capaz de surpreender, transplantar, numa gradação teórica e emotiva que partiria de Baudelaire e que justificaria um certo lugar da arte como "distração": "força que atrai, que absorve as forças disponíveis daquele que se aproxima".

Alter ego, entretanto, também sob a dupla postulação de Baudelaire, isto é, príncipe e bufão, e que caracterizaria a mitologia romântica do artista, a máscara, da qual o poeta conservaria uma consciência aguda de seu caráter encenado ${ }^{22}$. No poema de Max Jacob, está na representação que se alterna entre Don Juan, Rothschild, Fausto e um pintor, todos discutindo sobre a infelicidade da conquista amorosa. Mostra-nos um distanciamento frequente ao poeta, de um eu que põe e retira a cada momento a máscara do clown trágico, mesmo sob a forma teatral do diálogo ou por meio da alternância entre o "eu" e o "ele", em poemas como "Il pleurait sur son infortune".

Em Max Jacob, tal distanciamento está ainda na imagem do pierrô negro com uma fita azul da ordem do Santo Espírito, em "Pierrot n'a pas droit aux statues". Surge sem máscara, diferentemente das representações habituais do arlequim na Commedia dell'Arte, sofrendo de amor - sofrimento que seria em Jacob o não reconhecimento, "sem direito a estátuas". Lembra-nos do eu melancólico de "Paisagem no 3" de Mário de Andrade, pondo e desvestindo a máscara, como se representasse

21 Le cornet à dés. op. cit., p. 22-23.

22 Cf. STAROBINSKI, Jean. Sur quelques répondants allégoriques du poète. Baudelaire, Révue d'Histoire Littéraire de la France, Armand Colin, avril-juin, 1967. 
permanentemente a transfiguração do arlequim insolente, e solar, em humilde e noturno pierrô.

Ali em frente... - Mário, põe a máscara!

- Tens razão, minha Loucura, tens razão.

O rei de Tule jogou a taça ao mar. ${ }^{23}$

O gesto talvez aprofunde o movimento do poema de Max Jacob, sobre o rei que se recolhe ao monastério, abandonando, de certo modo, a taça do amor, como na lenda do Fausto de Goethe. Certo dia, o rei se levanta, bebe um pouco e arremessa a taça ao mar, morrendo logo em seguida. Na peça, o trecho é uma canção entoada por Margarida no instante que separa a entrada clandestina em seu quarto de Fausto e a descoberta por Mefistófeles, pouco depois, de um cofrezinho deixado no armário como presente. $\mathrm{O}$ destino da personagem, que é a recusa e a impossibilidade do amor, é antecipado pela bela canção:

\section{A taça caiu no mar \\ Que em turbilhão a acolheu, \\ Com os olhos viu-a afundar, \\ Nunca mais nela bebeu. ${ }^{24}$}

No poema de Mário, o eu observaria a partir daí os homens que passam encharcados no dia chuvoso, numa espécie de transbordamento afetivo que percorre grande parte dos poemas de Paulicéia desvairada, acompanhados por uma lágrima que escorre - "um fio de lágrimas sem nome", "um gosto de lágrimas na boca”. São lágrimas de um pierrô trágico ou, como diria Manuel Bandeira, a quem Mário dedica o longo poema "Carnaval carioca" de Clã do jabuti: "O meu carnaval sem nenhuma alegria". Sentimentos antitéticos que o poeta expressa com a presença da chuva e do sol, do sorriso e da tristeza da garoa, buscando uma pluralidade de estados da alma, que Max Jacob transferiria para a dimensão religiosa num trecho de "Visions infernales":

23 ANDRADE, Mário de. Poesias completas. Edição crítica de Diléa Zanotto Manfio. Belo Horizonte/ Rio de Janeiro: Villa Rica, 1993. p. 99.

24 GOETHE, Johann Wolfgang von. Fausto. Trad. Alberto Maximiliano. São Paulo: Nova Cultural, 2002. p. 123. 
Os vitrais da Igreja erguiam suas lágrimas para o céu enigmático da manhã e as árvores do square tinham sorrisos irônicos em sua folhagem movente. ${ }^{25}$

A menção ao De profundis, supondo nele a inclusão de um verso de Crisfal, "canto do mal de amor", do século XVI, parece retomar, além disso, no poema "Paisagem no 3" de Mário, o título de um dos poemas de A costela de grão cão. Está na referência a outro "mal de amor", que é a história do rei $^{26}$, tematizando ainda, segundo João Luís Lafetá, a crise de um ser em busca de sua identidade mutilada. Mythos latente, dividido em quatro fases: conflito, paixão, despedaçamento e reconhecimento busca dolorosa da identidade também em Max Jacob ${ }^{27}$. No poema, o mito é tramado por essas histórias e menções cruzadas, naquilo que o poema faria questão de definir como "paradoxal".

São jogos de antinomias que deslocam permanentemente o leitor a partir de uma sucessão de referências ou das inúmeras leituras musicais do episódio do rei de Tule, por Liszt, Schubert, Berlioz. Antinomia entre a lágrima nos olhos e a alegria da festa, que aparece na tradução de Gérard de Nerval do episódio do Fausto, de que se serve Berlioz:

Comme elle ne le quittait guère

Dans les festins les plus joyeux, Toujours une larme légère

À sa vue humectait ses yeux. ${ }^{28}$

Ou entre rei e bufão, razão e loucura, abandono e condição mascarada. E que faria com que Jean Cocteau, em 1918, no livro Le coqet l'arlequin preferisse o canto do galo a todas essas contradições do arlequim eclético. Talvez porque na personagem da Comedia dell'Arte essa alternância incômoda de lugares do eu, ou em virtude de uma ideia de superficialidade do arlequim - que, embora não exclua o breve, $o$ alegre, a elegância,

25 JACOB, Max. Visions infernales. In: . Ballades suivi de Visions infernales, Fond de l'eau, Sacrifice impérial, Rivage, Les Pénitents en maillots roses. Préface de Claude Roy. Paris: Gallimard, 1970. p. 111.

26 A écloga foi atribuída a Cristóvão Falcão (1515-1557).

27 LAFETÁ, João Luís. Figurações da intimidade: imagens na poesia de Mário de Andrade. São Paulo: Martins Fontes, 1986. p. 218.

28 GOETHE, Johann Wolfgang von. Faust. Trad. Gérard de Nerval. Paris: Charles Gosselin, 1853. p. 88 . 
- pudesse parecer mais próxima de uma comunicação com o público, desprestigiado nesse texto de Cocteau em defesa de Satie ${ }^{29}$.

Não é o caso de Mário e de Max Jacob, que entretêm relações também ambivalentes com o público - "Que me importa si me não entendem?" -, e a que se somaria um catolicismo apologético cheio de santos e personagens bíblicas em Max Jacob, conferindo-lhe a cada instante um deslocamento e uma profundidade, com a loucura do arlequim correspondendo, ademais, à possibilidade de um verdadeiro lirismo $^{30}$. Lembra-nos de que Max Jacob jamais compreendeu que o místico pudesse excluir o cômico, - e o espiritual, o burlesco, nas palavras de André Blanchet. Mesmo na produção pós-conversão, preserva recursos deruptura, parênteses explícitos às preces, elipses, interrupções, embora fosse restringindo gradativamente o seu emprego ${ }^{31}$.

Trata-se de uma dimensão religiosa que esteve presente também em Há uma gota de sangue em cada poema, de Mário de Andrade, como ideal cristão mais do que retomada de seus temas, que, porém, não deixam de figurar em vários poemas de Paulicéia desvairada e O losango cáqui. Em "Religião", no eu dividido que pede a Nossa Senhora a "Hospedaria dos jamais iluminados", apesar de depositar-lhe "a coroa de luz de minha loucura". Em "Jorobabel", tematizando em chave religiosa, a partir do Antigo Testamento, alguns dos conflitos do livro: a dispersão de vozes na metrópole, o transbordamento da vida e do choro, a incompreensão e a incomunicabilidade do poeta solitário. Num poema de O losango cáqui:

Ninguém sabe da solitude

Que enche o meu peito sem emprego,

$\mathrm{O}$ qual comunga todo dia

Na missa-baixa do abandono. ${ }^{32}$

29 COCTEAU, Jean. Le coq et l'arlequin. In: Le rappel à l'ordre: romans, poésies, œuvres diverses. Paris: La Pochothèque, 1995. p. 4,27.

zo JACOB, Max. Art poétique. Paris: Emile Paul, 1922. p. 63.

31 BLANCHET, André. Introduction. In: JACOB, Max. La défense de Tartufe: extases, remords, visions, prières, poèmes et méditations d'un juif converti. Paris: Gallimard, 1964. p. 39. A observação é também de Christine Van Rogger-Andreucci, no verbete do Dictionnaire de poésie: de Baudelaire à nos jours. Publié sous la direction de Michel Jarrety. Paris: Presses Universitaires de France, 2ool. p. 371. O losango cáqui. op.cit., p. 154. 


\section{Máscaras e sinceridade}

Para João Luís Lafetá, as diversas variações da primeira poesia de Mário de Andrade vão desde o "consumo subjetivista da função emotiva até a utilização da função mágica, do coloquial ou da metalinguagem”. São mudanças de tom e registro, muitas vezes justificadas por uma loucura que o poeta assume como sua condição primordial - e que é o momento, em A escrava que não é Isaura, em que menciona Max Jacob e seu "asilo dos degenerados superiores" ${ }^{33}$. A loucura está na base do que chamaria de "impulsão lírica” em Paulicéia desvairada, responsável por toda a dificuldade em saber "onde termina a blague, onde principia a seriedade" 34 . Produz oscilações tanto mais dramáticas quanto mais encenadas por uma escrita a um só tempo confessional e humorada, falando dos próprios sentimentos com os quais conjuga "primaveras de sarcasmo". Oposição que podemos percorrer em Max Jacob nos diversos contrastes entre poemas líricos e poemas intencionais ou, como chamaria Jean Rousselot, entre pseudoingenuidade e profundo sentido construtivo ${ }^{35}$.

Num primeiro momento, trata-se da necessidade de investigação das vanguardas, manifestando-se em versos antitéticos, interrupções bruscas, sincronismos, dissonâncias, trocadilhos, multiplicação de referências:

Meu pai com seu nariz judeu

Eu vivia quase sem ruído.

Dúmas Terrail Zóla escondidos

Si ele souber... Meu pai? Meu Deus? ${ }^{36}$

Investigação formal que aparece na estrutura de repetições sonoras, espécie de trampolim vocal que Max Jacob exploraria na homofonia de segmentos, em rimas internas e parelhas, em poemas intraduzíveis, como "Véritable petit orchestre":

Saint sein! vive le rein!

Vive le vin divin du Rhin

Où Chio? ou Ténédo? louez l'Ohio.

Point! Point! Point!

33 Idem, ibidem, p. 245 .

34. Os trechos provêm do "Prefácio interessantíssimo", fragmentos 4 e 4,2.

35 ROUSSELOT, Jean. Max Jacob au sérieux: essai. Rodez: Éditions Subervie, 1958. p. 158.

36 ANDRADE, Mário de. A escrivaninha. In: O losango cáqui, op. cit., p. 139. 
Segundo Telê Ancona Lopes, o arlequim e a loucura seriam um “instrumento de organização desejoso de enxergar além das aparências, percebendo que o lírico poderia estar fundido ao dramático, ao patético". Ofereceriam um tipo de conhecimento mais profundo, ligando "o plano dos sentimentos (o lírico) aos planos estético e ideológico"37.

No caso de Mário de Andrade, é possível situar essa profundidade por meio das duas figuras do eu no "Prefácio interessantíssimo": eu superior versus eu profundo, colocando lado a lado a oposição de Henri Bergson e o superego freudiano. Dois eus, do prefácio e dos versos, como se o eu dos poemas também não se deslocasse constantemente para a condição do julgamento e do olhar à distância. Tira-se a máscara, põe-se outra, em perfeito acordo com a temática do eu múltiplo das vanguardas: "sou trezentos", "tenho todo um Mappa-mundi de estados-de-alma"38.

Apesar de não surgir como projeto articulado em Max Jacob, senão na série do "Baile de máscaras" de Le cornet à dés, há nessa multiplicidade o desejo de conciliação dos elementos variados da realidade, em sintonia com o unanimismo de Jules Romains. Para René Plantier, o poeta não deseja "recusar nenhum aspecto da experiência da vida"39. Com isso, o equilíbrio pretendido entre razão e loucura, e que fez com que Jacob jamais viesse a aderir ao surrealismo como abolição da vida interior, visando essa profundidade por vezes sob o signo da consciência culpada, como em Mário: "poço sem fundo das minhas erronias".

Trata-se de um gesto que antepõe à crise moral e identitária, para um eu sempre fragmentário, perpassado por realidades distintas, a necessidade de um desdobramento, de uma máscara, mas que conduz também à ideia de sinceridade. Em Jacob, a partir do desejo de uma unidade moral, que é o trabalho ascético da criação, com suas disciplinas: prática do metier, inseparável de uma prática da virtude ${ }^{40}$. Faz da loucura criadora o caminho para a pertença a si: "Eu amo e é a minha

37 LOPEZ, Telê Ancona. op. cit., p. $z$.

38 A temática do eu múltiplo em Mário de Andrade é mais complexa e comporta outras referências. Uma delas está na marginália do livro A estrella do absynto, de Oswald de Andrade, conforme indicada por Nites Theresinha Feres em Leituras em francês de Mário de Andrade, publicação do IEB, São Paulo, 1969: "Na psicologia literária até meios do séc. XIX, o herói era um tipo psicológico completo. Era psicológico a priori [...] Com os modernos literatos de psicologia, o herói propriamente se acabou. É o herói acumulativo em que se exploram, gradativamente, gestos, tendências, circunstâncias sem que duma se possa deduzir a seguinte. É o herói polifônico, simultaneista, Proust principalmente".

39 PLANTIER, René. L'Univers poétique de Max Jacob. Paris: Librairie Klincksieck, 1976. p. $3^{2}$.

40 Idem, ibidem, p. 399. 
loucura", afirma o eu do poema "Mélancolie au Sénéchal”. Noutro poema de Le laboratoire central:

Pois tudo isso é só loucura que imagino

Para dizer minha tristeza e minhas grandes dores. ${ }^{41}$

De modo geral, o poeta desloca a reflexão sobre o arlequim ao assumir em sua variedade expressiva, na multiplicidade de sua forma e de suas máscaras, um movimento que instauraria uma outra relação entre eu e obra literária. Para René Plantier, a evolução da literatura levaria ao surgimento de uma nova sensibilidade, na qual "nem humor, nem jogos de palavras, nem a surpresa, nem a recusa de encontrar as palavras dos outros, a harmonia dos outros, nem a recusa da unidade de tom, são contrárias ao nascimento da emoção e do lirismo". A originalidade de Jacob estaria em "pensar a poesia em termos de meios expressivos e de efeitos"42. Meios expressivos, para dizer sobretudo da importância musical do verso, em conselhos como os que ofereceu ao poeta Charles Golblatt:

Você está progredindo mas teus versos não cantam o suficiente, não esqueça do ritmo, é a grande força do verso, componha como se estivesse cantando uma ária, não importa qual. A imagem é menos forte do que o ritmo, a imagem se dirige ao olho que não é nada em poesia, o ritmo vai direto ao coração, o romance é por excelência a poesia. ${ }^{43}$

Daí uma ideia de artesanato como um lugar da prática moral sob o signo da humilitas - em Mário, como esforço de desalienação e contra a "vaidade de ser artista"44. Plena compreensão de suas virtualidades expressivas, em que o aprofundamento do humano se fundaria no espaço de uma linguagem criadora, no sentido de uma força expressiva capaz de dotá-la de realidade. "O que chamamos uma obra sincera é

41 JACOB, Max. Le laboratoire central. op. cit., p. 83.

42 PLANTIER, René. op. cit., p. 398.

43 JACOB, Max. L'Amitiè, lettres à Charles Goldblatt. Édition établie et présentée par André Rounieux. Paris: Le Castor Astral, 1994. p. 75.

44. ANDRADE, Mário de. O artista e o artesão. In:___ . O baile das quatro artes. 3. ed. São Paulo: Martins, 1975. p. 32. Humilitas também em Mário: “Na história das artes, estamos num período que muito parece ter pesquisado e que, no entanto, é dos mais afirmativos, dos mais vaidosos, dos menos humildes diante da obra de arte". 
aquela dotada de força suficiente para oferecer realidade à ilusão" ${ }^{45}$, diz Max Jacob. Força expressiva, segundo Albert Béguin, com a qual o poeta francês esperaria “desvendar os segredos do silêncio interior, na célula onde a criatura se esconde na companhia de seu Deus"

Em Mário de Andrade, a noção de sinceridade está no artigo "Do cabotinismo", de O Empalhador de passarinho, mais tarde investigado por Anatol Rosenfeld ${ }^{47}$. Ela comporta várias dimensões. A primeira delas, que desdobra a ideia do artesanato em Max Jacob, situa-se diante de uma oscilação entre a noção de sinceridade do indivíduo e sinceridade da obra de arte $^{48}$. Tal duplicidade passa evidentemente pela influência de Paul Dermée, que esteve próximo de Apollinaire, de Max Jacob e da revista Esprit nouveau, ao compreender a criação a partir de um misto de impulsão lírica do inconsciente e de trabalho da inteligência ${ }^{49}$. Mostra como à intimidade da condição poética seria preciso somar a exatidão do trabalho artístico. Sinceridade da arte, nesse sentido, para não colocá-la apenas na trilha de poetas como Francis Jammes e Paul Fort: "lirismo da sinceridade", segundo Michel Décaudin ${ }^{50}$, porque em constante tentativa de equilíbrio com a ideia de construção, desde Klaxon, que tinha como lema: "Era do riso e da sinceridade. Era da construção".

Porém, sobretudo a partir dos anos 1930, em ensaios como "A raposa e o tostão" e "O artista e o artesão", em face de uma série de valores que passa a defender. Um deles, a desconfiança do alcance poético de um assunto quando desprovido do artesanato da poesia. É o momento em que critica autores que teriam se dobrado às exigências do mercado literário, cabotinos, insinceros. Artesanato, como em Jacob, baseado numa moralidade profissional, embora, no poeta paulista, contra uma "inflação do artista”, numa dialética que João Luís Lafetá explorou nos capítulos "Ética e poética" e "O artista e a sociedade" do livro 1930: $a$ crítica e o modernismo.

45 JACOB, Max. Art poétique. op. cit., p. 22. O trecho está assinalado com um x na edição da Coleção Mário de Andrade.

46 BÉGUIN, Albert. Poésie de la présence, de Chrétien de Troyes à Pierre Emmanuel. Neuchâtel/ Paris: À La Bacconnière/ Éditions du Seuil, 1957. p. 283.

47 ROSENFELD, Anatol. Letras e leituras. São Paulo/Campinas: Perspectiva/Edusp/ Editora da Unicamp, 1994. p. 95-116.

48 Cf. também “O Movimento modernista”. In: ANDRADE, Mário de. Aspectos da literatura brasileira. São Paulo: Martins, 1967. p. 234.

49 GREMBECKL, Maria Helena. Mário de Andrade e L'Esprit nouveau. São Paulo: Instituto de Estudos Brasileiros, 1969.

50 DÉCAUDIN, Michel. La crise des valeurs symbolistes, vingt ans de poésie française (I8I519I4). Thèse pour le Doctorat ès Lettres présentée à la Faculté de Lettres de l'Université de Paris. Éditions Privat. Toulouse, 1960. p. 53. 
Tal moralidade aponta para uma segunda dimensão da noção de sinceridade, valorizando a técnica como forma de ampliar um alcance coletivo da arte. De algum modo, é o caminho já traçado desde o ensaio "Luzes e refrações", do número 1 de Klaxon, quando afirma: "A sinceridade em arte não consiste em reproduzir, senão em criar. O seu princípio gerador é a 'consciência singular', pelo qual um homem é verdadeiramente digno de ser chamado poeta - isto é: criador"51.

Por coletivo, indica o desejo de uma poesia, a um só tempo pessoal, mas também em sintonia como uma autenticidade cultural da nação, investindo na "criação" como resposta à simples "reprodução" de modelos exteriores. Plasmando de forma consciente a sua identidade, diz-nos Rosenfeld, por meio da conformação de valores de outras culturas, “de tal modo que máscara e ser já não são mais separáveis". Sinceridade da arte que passa, portanto, pela cristalização de suas formas expressivas, às quais se somaria a procura por uma linguagem artística capaz de desfazer as tensões entre língua popular e literária. São impulsos de intelectual no papel de formador da nacionalidade, e que inserem o poeta brasileiro numa tradição empenhada à qual Max Jacob jamais pertenceria.

É o que nos permite considerar, por fim, uma terceira dimensão da sinceridade em Mário de Andrade. Para ele, há um desejo de responder a seu público, que chamaria de cabotinismo: "o artista completo jamais perderá de vista a ambição de se tornar ou se conservar célebre" ${ }^{52}$. Insincero, ele assumiria por vezes uma atitude preliminar, vista de forma negativa mesmo em autores como Murilo Mendes, Jorge de Lima, Schmidt e Graça Aranha, como em carta de 1942 destinada a Henriqueta Lisboa, em que brinca: "Bom, tenho que fazer um poema sobre qualquer um dos valores eternos" ${ }^{53}$. Noutros momentos, o artista tenderia a uma intenção social ou à repetição de processos artísticos bem-sucedidos: concessões ao público que Mário pôs sob o signo da demagogia em "A raposa e o tostão", que trazia um repúdio à literatura realista e à mercantilização do trabalho literário, como já se assinalou. Finalmente,

51 Klaxon, n. ı. São Paulo, 1922, p. 16.

52 ANDRADE, Mário de. Do cabotinismo. In: O empalhador de passarinho. 2. ed. São Paulo: Martins, 1955. p. 78.

53 Idem. Querida Henriqueta: cartas de Mário de Andrade a Henriqueta Lisboa. op. cit., p. 145. De algum modo, é a mesma atitude preliminar que critica em Henriqueta: “[...] tem em você agora, com certa indecisão, imprecisão de divisão, duas pessoas distintas. Uma delas é o Poeta, a outra é a Professora Católica. [...] Ambas as duas pessoas são igualmente respeitáveis, mas, está claro também que a professora 'religiosa', quando se intromete, si às vezes ainda consegue fazer coisas integrais de poesia, com mais freqüência, estraga bem a consciência lírica da poesia”. 
o artista poderia incorrer num "mau ecletismo", "que é acomodatício e máscara de todas as covardias", para o qual o professor de estética dos anos 1930, no ensaio "O artista e o artesão", sugere a aquisição de uma atitude artística verdadeira ${ }^{54}$.

A máscara do artista cabotino se fundaria, no entanto, também num distanciamento positivo. Como observa Anatol Rosenfeld, corresponde a uma distância da pessoa com relação a si mesma. Para Mário, com inteligência, o artista venceria "tudo o que de vil, de mesquinho, de repugnante possa originar a nossa vida e nossos gestos". Seria uma espécie de cabotinismo "nobre, necessário, maravilhosamente fecundo" 55 , cuja trajetória ascética não deixa de ir de par com uma visada também ambígua para as classes sociais com as quais essa arte dialoga e que pretende representar.

\section{Burgueses da França e de alhures}

L'argent et l'opinion, la bêtise d'autrui

Ont fait de moi le dur bourgeois que signe ici.

[O dinheiro, a estupidez de outrem, a verrina

Tornaram-me o duro burguês que aqui assina.]

O dístico acima fecha um poema de Max Jacob intitulado "Établissement d'une communauté au Brésil". Nele a comunidade de monges que decide habitar a floresta, entre bananas e antílopes, é destruída por negros "sem que o azul fremisse diante da morte". Uma estrofe ao fim permite, entretanto, um recuo para esse eu que "vestido de inocência e de amor" segue trabalhando. Atento aos outros, diz-nos ser ele mesmo burguês, duro burguês, como se a opinião de outrem, a "estupidez de outrem" e o dinheiro, afirma o poema, tivessem mudado a sua própria condição.

Max Jacob escreveu um livro intitulado Bourgeois de France et d'ailleurs, no qual fez retratos da burguesia, "portraire la Bourgeoisie", não sem o embaraço de ter nascido em seu seio, contradição que Jean Cocteau observou em Baudelaire:

54. Idem. O artista e o artesão. In: O baile das quatro artes. op. cit., p. 26.

55 Idem. A raposa e o tostão. In: O empalhador de passarinho. op. cit., p. 8 o. 
É preciso perder um preconceito baudelariano; Baudelaire é um burguês. A burguesia é a grande cepa da França; todos os nossos artistas saem daí. Filhos de famílias emancipadas. Talvez eles consigam se libertar, mas ela lhes permite construir perigosamente sobre uma base..$^{56}$

O exemplo de Baudelaire afirma a dificuldade de uma burguesia que é origem e distância, e da qual seria preciso libertar-se. "Se não tivesse nascido nela e não a conhecesse, não me importaria em descrevê-la", afirma Max Jacob ${ }^{57}$. Todavia, como no poema, ela constitui a possibilidade da escrita, da perigosa escrita, tanto quanto da assinatura. É indissociável de um movimento que está na base da modernidade artística, na individualidade que imprime a sua marca, fazendo do estilo um valor (também com sentido econômico), que Jean-François Lyotard viu como resposta niilista à angústia da megalópole, num ensaio em que lembrou o poeta francês. Niilismo que seria um dos sinais que desdobraria o objeto e o corpo em facetas e esboços, na interpretação que propôs das noções de estilo e situação de Le cornet à dés ${ }^{58}$.

Talvez pudéssemos trilhar a partir daí alguns caminhos sobre a noção de sublime, de uma demanda insatisfeita do sublime na modernidade e que o colocaria, contraditoriamente, sob a perspectiva do excesso. Sublime relacionado com o irracional, com uma catástrofe para além do humano. Permite-nos indicar no dilaceramento de Mário, com o auxílio de João Luís Lafetá, uma resposta ao dilaceramento da sociedade: "mundo de exílios, depredações, mortes e tiranias" ${ }^{\text {59 }}$. A metrópole se esfacelaria na consciência de um eu inquieto, ambos excessivos, multifacetados, "cubistas", incapazes de resolver a tensão entre representação do eu e da cidade, numa sensação permanente de incompletude, desequilíbrio, dissonância.

Mas o esfacelamento provém também da dificuldade de representar as suas classes sociais. "Confesso que estou bem embaraçado", diz-nos Max Jacob. Há como um modo do "deslizar” que é, a um só tempo, a condição do arlequim e do poeta moderno flaneur, incapaz de aderir, embora fascinado, ao mundo das cidades e àqueles que nela transitam.

56 COCTEAU, Jean. op. cit., p. 429.

57 JACOB, Max. Bourgeois de France et d'ailleurs. Paris: Gallimard, 1932. p. 7.

58 LYOTARD, Jean-François. Moralidades pós-modernas. Trad. Marina Appenzeller. Campinas: Papirus, 1993. p. 31. A interpretação está situada com relação a um conjunto de preocupações de Lyotard que escapam ao propósito deste ensaio, e que fazem de Jacob um niilista que rejeitaria o "princípio romântico da vida".

59 LAFETÁ, João Luís. Figurações da intimidade: imagem na poesia de Mário de Andrade. op. cit., p. 115 . 
Encena a possibilidade de um olhar oblíquo, à distância, como no poema "Petite ville anglaise le dimanche", conjugando-o com certa adesão sentimental à vida urbana.

Num antigo letreiro de um antigo bazar

Avistamos o nome Company Balthasar.

No gelo das ruas deslizam senhores viúvos,

As calçadas arrasadas da véspera estão novas.

$[\ldots]$

Mas eu, cobrador de impostos indiretos

Tenho a cabeça num domingo na altura dos insetos

Um sol incendeia minha toalha de camisa

Essa manhã rezei três horas numa missa

Será que estou dormindo ou se desperto

Há um violão por perto ${ }^{60}$

É o mesmo que ocorre no poema "Domingo", de Paulicéia desvairada, com um eu que observa as famílias, os automóveis fechados, repetindo o refrão no fim de cada estrofe: "futilidade, civilização". Olhar enviesado, "acrobático", que percorre os luxos da cidade, os vestidos, conta o dinheiro. Traz uma dimensão do burguês aquém de toda vida espiritual e moral, que Max Jacob representaria em poemas como "Familles chrétiennes", de Derniers роèmes. Vida espiritual, para indicar uma oposição entre arte e burguesia que é antiga. No Wilhelm Meister de Goethe, percorre a trama inicial, envolvendo o próprio Wilhelm e Melina, ambos diante da contrariedade entre existência artística e a possibilidade de ter um simples emprego. "E assim, contra sua vontade, Melina teve de partir ao cabo de alguns dias, com sua jovem noiva, que já mostrava um desejo enorme de ver o mundo e pelo mundo ser vista, e foi à procura de uma colocação numa companhia qualquer" ${ }^{61}$.

Burguesia estabelecida sobre uma moral do trabalho, a qual Max Jacob acrescentaria, às vezes, uma outra, excessiva, do luxo:

Apreciar o luxo é símbolo de grandeza de alma. Julgar as pessoas pelo mais ou menos luxo que ostentam, é julgar a própria capacidade que têm de ganhar dinheiro, e ganhar dinheiro, no fundo, é

6o JACOB, Max. Le laboratoire central. op. cit., p. 187.

61 GOETHE, Johann Wolfgang von. Os anos de aprendizado de Wilhelm Meister. Trad. Nicolino Simone Neto. São Paulo: Editora 34, São Paulo, 20o6. p. 70. 
o que conta na vida, não? De mais a mais, com que outros meios poderíamos avaliar as pessoas? ${ }^{62}$

São excessos que contrastam com o burguês "pouco-a-pouco" de Mário, "purée de batatas morais", "cheirando religião e que não crê em Deus", e que seria, de certo modo, como as personagens "Monsieur très bien", gordo industrial, e "La dame très bien" e seu amante de Dos d'arlequin de Jacob, com seus conflitos conjugais motivados pelo dinheiro - e é divertida a advertência do marido à mulher, dizendo-lhe que terminará seus dias afogada no lago da casa, ao qual ela se lança posteriormente de bom grado. Burgueses de que Mário também faz a caricatura, mesmo que volte atrás no poema XXIII de O losango cáqui, talvez para mostrar que uma ligação afetiva com a cidade ultrapassaria o desejo do eu de "classificar sentimentos lícitos e ilícitos do ponto de vista da contemporaneidade" ${ }^{63}$.

De todo modo, sob o signo do "épater le bourgeois", escreve a esse burguês de quem não deixa de ser, em certa medida, cúmplice.

Tal oscilação, como se pode notar, retoma as máscaras do arlequim, que se estica como a rua elástica do poema "Rondó do tempo presente". Desfaz, no entanto, a cada momento, a possibilidade de assumir uma voz com feição de classes definida. Estratégia que não deixa de ser profundamente pessoal como projeto poético, e que se acompanhará em Mário de uma crítica a si mesmo, no ensaio "O movimento modernista", no qual afirma ter deformado toda a sua obra em virtude de um "anti-individualismo dirigido e voluntarioso" e, portanto, individualista ${ }^{64}$. Há nela a tentativa de levar a expressão pessoal a outras personagens, num esforço agregador, como o de Max Jacob em Le cabinet noir, deixando cada uma assumir a sua escrita e os seus desejos.

Se em Mário tal deslizar acompanha-se de uma crítica ao artista; se contempla, igualmente, um questionamento sobre a nacionalidade, ao escolher personagens como o cabo de O losango cáqui - "Cabo Machado, bandeira nacional!", que será o eu de vários poemas do livro -, noutros momentos, como no poeta francês, não deixa de encenar com "alegria triste”, por assim dizer, a fragmentação a que as transformações sociais submetem essas mesmas personagens. Sensação de deslocamento, no cabo que marcha de forma "muito pouco marcial": "Marcha vem-cá-mulata".

62 JACOB, Max. Le cabinet noir. Paris: Gallimard, 1977. p. 40. Cito na tradução inédita de Luiz Dantas.

63 "Identificação humanitária de cristão", para Telê Ancona Lopez. op. cit., p. 22.

64 ANDRADE, Mário de. O losango cáqui. op. cit., p. 254. 
$\mathrm{Ou}$ de isolamento, em ensaios posteriores. Isolamento de um eu-arlequim que não se quer distraído e alienado, e cuja atenção para com o outro esbarra no desejo e na distração das formas poéticas novas.

Se o poeta-arlequim pode ser o pai de família burguês, em Max Jacob, com seus problemas conjugais no poema "La marâtre moderne", ou se é o noivo cuja mãe está aflita com o casamento por causa da diferença de idade, no poema "Paysage", há uma preferência em Mário pelos homens "fracos, baixos, magros", como os que giram no poema "Os cortejos". A dificuldade de representá-los faz deles homens "iguais e desiguais", que passam pela cidade devoradora de "vaidades e mais vaidades", sob o signo do Eclesiastes. Homens sonolentos de "Paisagem no 2", doentios na Paulicéia cinza, numa espécie de desarmonia coletiva e pessoal.

Olhar para eles, no caso do poeta, para além de demarcar a afinidade com a caritas baudelairiana, mostra-nos o quanto o próprio eu e a sua linguagem se constroem também nesse outro lugar: "Então o poeta vai deitar", diz-nos um dos poemas de $O$ clã do jaboti. É o inconsciente do sono e da loucura como lugar do encontro de si. Mostra-nos também a duplicidade entre arte e humildade - no poeta que se distancia, a seu modo, da vida mundana - e que faz com que Max Jacob chame o trapeiro do poema "La rue Ravignan" de Dostoievski. "Defuntos da história” que recolhem os restos - ruína e abandono de Deus, no poema "La vraie ruine" - e cuja fragmentação transtorna a linguagem.

Nessa duplicidade assumida, o próprio Mário de Andrade marchará "tempestuoso noturno" no poema XVII de O losango cáqui. Acorda cedo com a vista que "renasce na manhã bonita", vai ao trabalho acompanhado de amigos íntimos, lembrando-nos de uma dimensão social com a qual se identificaria desde as suas primeiras leituras, nos anos 1915, com seus ideais de "confraternização universal", diz-nos o poema ${ }^{65}$. Mas é também o poeta da dor ante a identificação precária, perpassada pela língua. A Pauliceia torna-se a Babel de uma guerra que é traçada também aí, com seus signos religiosos, ilusões, imoralidades, para olhos que de tão oblíquos, ou se fecham no sono, ou cortam.

E marcho tempestuoso noturno.

Minha alma cidade das greves sangrentas, Inferno fogo INFERNO em meu peito, Insolências blasfêmias bocagens na língua.

Meus olhos navalhando a vida detestada. ${ }^{66}$

65 LOPEZ, Telê Ancona. op. cit., p. 29 e 71.

66 ANDRADE, Mário de. O losango cáqui. op. cit., p. 135. 


\section{Imagens do artigo:}

Deslizar nas ruas, entre Max Jacob e Mário de Andrade

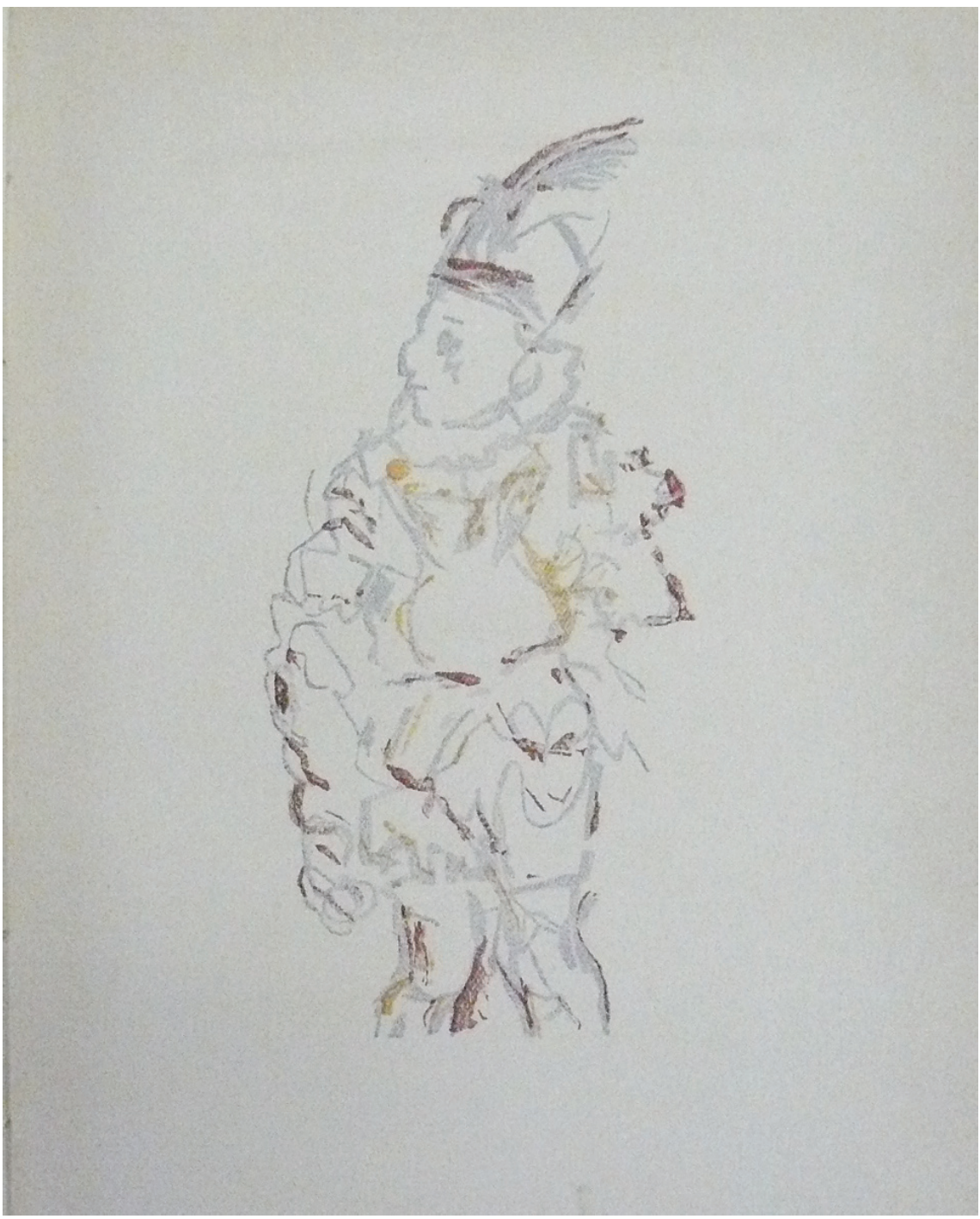

Figura 1. Gravura de Dos d'Arlequin de Max Jacob. Reprodução do exemplar da Coleção Mário de Andrade. 